Correspondence Juergen Wiegel jwiegel@uga.edu

\section{Caldanaerovirga acetigignens gen. nov., sp. nov., an anaerobic xylanolytic, alkalithermophilic bacterium isolated from Trego Hot Spring, Nevada, USA}

\author{
Isaac D. Wagner, ${ }^{1}$ Sibtain Ahmed, ${ }^{2,3}$ Weidong Zhao, ${ }^{4,5}$ \\ Chuanlun L. Zhang, ${ }^{4,5}$ Christopher S. Romanek, ${ }^{5,6}$ Manfred Rohde $^{7}$ \\ and Juergen Wiegel ${ }^{1}$ \\ ${ }^{1}$ Department of Microbiology, University of Georgia, Athens, GA 30602-2605, USA \\ ${ }^{2}$ Department of Chemistry and Biochemistry, University of Agriculture, Faisalabad 38040, Pakistan \\ ${ }^{3}$ Department of Physiology and Biochemistry, University of Veterinary and Animal Sciences, Lahore \\ 54000, Pakistan \\ ${ }^{4}$ Department of Marine Sciences, University of Georgia, Athens, GA 30602, USA \\ ${ }^{5}$ Savannah River Ecology Laboratory, University of Georgia, Aiken, SC 29802, USA \\ ${ }^{6}$ Department of Geology, University of Georgia, Athens, GA 30602, USA \\ ${ }^{7}$ GBF-Gesellschaft für Biotechnologische Forschung GmbH, D-38124 Braunschweig, Germany
}

An anaerobic thermophilic bacterium, designated strain JW/SA-NV4 ${ }^{\top}$, was isolated from a xylansupplemented enrichment culture from Trego hot spring located within the Black Rock Desert (NV, USA). Cells were generally straight or slightly bent rod-shaped, $0.4-0.8 \mu \mathrm{m}$ in width and 3-6 $\mu \mathrm{m}$ in length during exponential growth. Cells from stationary phase were variable in size and shape, showing curved or bent morphology. Motility was not seen and flagella were not observed in electron micrographs. Sporulation was not observed. Strain JW/SA-NV4 ${ }^{\top}$ stained Gramnegative but is phylogenetically Gram-type positive. Growth occurred at $\mathrm{pH}^{25}{ }^{\circ} \mathrm{C} 6.8-8.8$, with optimum growth at $\mathrm{pH} 8.4$; no growth occurred at $\mathrm{pH} 9.0$ or above or at 6.5 or below. With glucose or xylose as the carbon source, strain JW/SA-NV $4^{\top}$ grew at $44-74{ }^{\circ} \mathrm{C}$; no growth occurred at $76{ }^{\circ} \mathrm{C}$ or above or at $42^{\circ} \mathrm{C}$ or below. However, the optimum temperature was 62 and $66{ }^{\circ} \mathrm{C}$ when grown on glucose and xylose, respectively. The shortest doubling time observed with glucose was approximately $4 \mathrm{~h}$, and with xylose approximately $3.4 \mathrm{~h}$. Strain JW/SA-NV4 ${ }^{\top}$ tolerated an atmosphere containing up to $0.1 \% \mathrm{O}_{2}$; no growth occurred at a gas atmosphere of $0.2 \% \mathrm{O}_{2}$. Chemo-organotrophic growth occurred with xylose, glucose, mannose, xylan, pyruvate, fructose, ribose, Casamino acids, mannitol, tryptone, peptone, cellobiose and yeast extract. When grown in mineral media containing $1 \mathrm{~g}$ yeast extract $\mathrm{I}^{-1}$ as an electron donor, thiosulfate and sulfur were reduced to sulfide. The $\mathrm{G}+\mathrm{C}$ content of the DNA was $38.6 \mathrm{~mol} \%$ (HPLC). $16 \mathrm{~S}$ rRNA gene sequence analysis placed strain JW/SA-NV $4^{\top}$ within the order Thermoanaerobacterales and within the Thermoanaerobacterales Incertae Sedis Family III, specifically between taxa classified within the genera Thermosediminibacter and Thermovenabulum. The closest phylogenetic neighbours were Thermosediminibacter oceani JW/IW-1228P $\mathrm{P}^{\top}$ (94.2\% 16S rRNA gene sequence similarity) and Thermosediminibacter litoriperuensis JW/YJL-1230-7/2 ${ }^{\top}$ (94.0\%) [Lee, Y.-J., Wagner, I. D., Brice, M. E., Kevbrin, V. V., Mills, G. L., Romanek, C. S. \& Wiegel, J. (2005). Extremophiles 9, 375-383]. Based on physiological and genotypic characteristics, strain JW/SA$\mathrm{NV} 4^{\top}$ (=DSM $18802^{\top}=$ ATCC BAA $\left.-1454^{\top}\right)$ is proposed to represent the type strain of a novel species in a novel genus, Caldanaerovirga acetigignens gen. nov., sp. nov. 
The numerous hot springs distributed throughout northern Nevada, USA, are the result of the Pacific and North American tectonic plates colliding and the circulation of meteoric waters along Basin and Range faults (Hose \& Taylor, 1974; Pearson et al., 2004). In addition, several of the hot springs in northern Nevada are alkaline from the bleaching of carbonate or silica-bearing rocks by hot water. Alkaline hot springs with $\mathrm{pH}$ values above 8.5 are less common than slightly and strongly acidic hot springs and are studied less frequently. One consequence is that alkalithermophiles, Bacteria and Archaea that grow at elevated temperatures (optimum $>50{ }^{\circ} \mathrm{C}$ ) and high $\mathrm{pH}$ (optimum $\geqslant 8.5$ ), have received less attention than the acidophilic or neutrophilic thermophiles (Kevbrin et al., 2004; Wiegel, 1998). Here we report on the isolation of a moderately alkalithermophilic anaerobe growing on hemicellulosic material. Xylan is a component of plant hemicellulose and the second-most abundant renewable polysaccharide. Xylanolytic micro-organisms attract interest because the conversion of xylan to useful products could possibly be coupled to increasing the efficiency of processing lignocellulose (e.g. pulping processes) and to the production of energy from renewable resources (Biely, 1985; Himmel et al., 2007). Xylan is widely used among thermophilic anaerobic Bacteria, especially among members of the Firmicutes, but is less studied in alkalithermophiles (Shao et al., 1995; Wagner \& Wiegel, 2008; Wiegel \& Kevbrin, 2004).

Water and sediment samples were collected from hot springs of northern Nevada at various sites, including Trego hot spring $\left(40^{\circ} 46^{\prime} 12^{\prime \prime} \mathrm{N} 119^{\circ} 6^{\prime} 46^{\prime \prime} \mathrm{W} ; 46.8^{\circ} \mathrm{C}\right.$ and $\mathrm{pH}$ 8.9). The samples were transferred to sterile anaerobic serum bottles, and sealed with butyl rubber stoppers. Enrichment cultures were prepared from these Nevada Hot Spring samples using an anaerobic carbonate- and TAPSbuffered medium containing $\left(1^{-1}\right): 0.272 \mathrm{~g} \mathrm{KH}_{2} \mathrm{PO}_{4}, 0.5 \mathrm{~g}$
$\mathrm{NH}_{4} \mathrm{Cl}, 0.5 \mathrm{~g}\left(\mathrm{NH}_{4}\right)_{2} \mathrm{SO}_{4}, 1.5 \mathrm{~g} \mathrm{NaHCO}, 2.43 \mathrm{~g}$ TAPS buffer, $0.02 \mathrm{~g} \mathrm{MgCl}_{2}, 0.015 \mathrm{~g} \mathrm{CaCl}, 1.0 \mathrm{ml}$ vitamin solution and $1.0 \mathrm{ml} \mathrm{Na} \mathrm{NeO}_{3}-\mathrm{Na}_{2} \mathrm{WO}_{3}$ trace-element solution (Widdel \& Bak, 1992) adjusted to either $\mathrm{pH} 8.5$

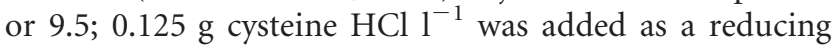
agent. Xylose or xylan was added after the medium had been autoclaved to a final concentration of 0.3 or $3.0 \mathrm{~g} \mathrm{l}^{-1}$, respectively. Initial incubations were performed at $62{ }^{\circ} \mathrm{C}$. After 5-7 days of incubation, growth was observed within the $\mathrm{pH} 8.5$ xylan- or xylose-supplemented enrichment cultures from Trego hot spring. Agar $(2.15 \% \mathrm{w} / \mathrm{v})$ shakeroll tubes were prepared, and single colonies from dilution series were sequentially isolated to obtain pure cultures (Ljungdahl \& Wiegel, 1986). Culture purity was checked by using phase-contrast microscopy and analysis of the $16 \mathrm{~S}$ rRNA gene sequence. Strain JW/SA-NV4 ${ }^{\mathrm{T}}$ was obtained and chosen for further study. For subsequent comparisons (see 16S rRNA gene sequence analysis below), Thermosediminibacter oceani JW/IW-1228 $\mathrm{P}^{\mathrm{T}}$ and Thermosediminibacter litoriperuensis JW/YJL-1230-7/2 ${ }^{\mathrm{T}}$ were obtained from laboratory stocks.

Within agar shake-roll tubes, colonies of JW/SA-NV4 ${ }^{\mathrm{T}}$ were $0.1-1.5 \mathrm{~mm}$ in diameter and irregularly shaped. During exponential growth in a liquid medium, cells of strain JW/SA-NV4 ${ }^{\mathrm{T}}$ were uniformly straight or slightly bent rod-shaped, $0.4-0.8 \mu \mathrm{m}$ in width and 3-6 $\mu \mathrm{m}$ in length. Short chains of two or three cells were frequently observed (Fig. 1a), but occasionally cells with lengths of $20-30 \mu \mathrm{m}$ were observed during exponential growth. Cells from stationary phase cultures were variable in size and shape; most noticeably, cells were often curved or bent (Fig. 1b). Strain JW/SA-NV4 ${ }^{\mathrm{T}}$ stained Gram-negative at all growth phases but is phylogenetically Gram-type positive (Wiegel, 1981). The formation of spores was not observed under various conditions including during growth on glucose,
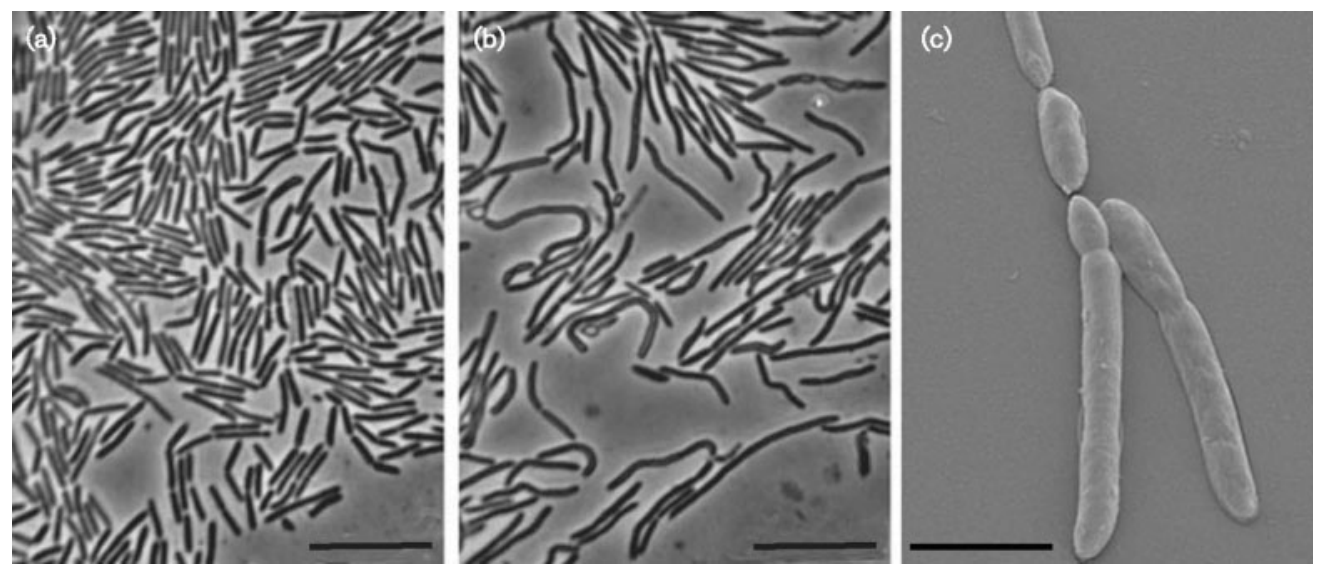

Fig. 1. Phase-contrast and electron micrographs of strain JW/SA-NV $4^{\top}$. (a) Cells from exponential phase cultures; bar, $10 \mu \mathrm{m}$. (b) Cells from stationary phase cultures; bar, $10 \mu \mathrm{m}$. Cells from stationary phase cultures are more variable in size and shape compared with cells from exponential phase cultures, which are generally straight or slightly bent rod-shaped, 0.4-0.8 $\mu \mathrm{m}$ in width and 3-6 $\mu \mathrm{m}$ in length. (c) Electron micrograph of strain JW/SA-NV4 ${ }^{\top}$; bar, $2 \mu \mathrm{m}$. 
beef extract, yeast extract-containing agar slants. No viability was observed when cultures were heated to $100{ }^{\circ} \mathrm{C}$ for $2 \mathrm{~min}$ as usual for thermophilic spore-forming anaerobic Firmicutes. Motility was not observed in cells from liquid culture and electron micrographs did not reveal flagella (Fig. 1c).

Temperature profile, $\mathrm{pH}$ profile, $\mathrm{NaCl}$ tolerance and substrate range were determined through measurement of $\Delta \mathrm{OD}_{600}$ using a Spectronic 21 spectrophotometer (Bausch and Lomb). A temperature-gradient incubator (Scientific Industries) was used to determine the temperature range and optimum for growth of JW/SA-NV4 ${ }^{\mathrm{T}}$ using the carbonate- and TAPS-buffered basal medium complemented with $1.0 \mathrm{~g}$ yeast extract $\mathrm{l}^{-1}$ and either $3.0 \mathrm{~g}$ glucose $\mathrm{l}^{-1}$ or $3.0 \mathrm{~g}$ xylose $1^{-1}$. With glucose as a provided carbon source $\left(\mathrm{pH}^{25}{ }^{\circ} \mathrm{C}\right.$ 8.1), strain JW/SA-NV4 ${ }^{\mathrm{T}}$ grew between 44 and $74{ }^{\circ} \mathrm{C}$, and optimally at about $62{ }^{\circ} \mathrm{C}$; after more than $200 \mathrm{~h}$ of incubation, no growth was observed at or below $42{ }^{\circ} \mathrm{C}$, or at $77^{\circ} \mathrm{C}$ or above. With xylose as the provided carbon substrate $\left(\mathrm{pH}^{25}{ }^{\circ} \mathrm{C}\right.$ 8.2), strain JW/SA-NV4 $4^{\mathrm{T}}$ grew between 46 and $76{ }^{\circ} \mathrm{C}$, and optimally around $66^{\circ} \mathrm{C}$; after more than $300 \mathrm{~h}$ of incubation, no growth was observed at or below $44{ }^{\circ} \mathrm{C}$, or at $78{ }^{\circ} \mathrm{C}$ or above. In medium containing $1.0 \mathrm{~g}$ yeast extract $\mathrm{l}^{-1}$

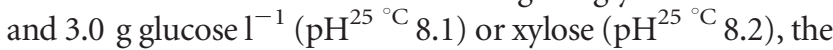
shortest doubling time was approximately $4 \mathrm{~h}$ (glucose) and $3.4 \mathrm{~h}$ (xylose). To determine the $\mathrm{pH}$ profile of strain JW/SA$\mathrm{NV}^{\mathrm{T}}, 3 \mathrm{~g} \mathrm{l}^{-1}$ glucose-containing media were buffered with $10 \mathrm{mM}$ each of TES, TAPS and CAPS. Growth occurred between $\mathrm{pH}^{25}{ }^{\circ} \mathrm{C} 6.8$ and 8.8 , with optimum growth at $\mathrm{pH} 8.4$; no growth occurred at $\mathrm{pH} 9.0$ or above or at 6.5 or below. Strain JW/SA-NV4 $4^{\mathrm{T}}$ grew in medium containing up to $4.0 \%$ $(\mathrm{w} / \mathrm{v}) \mathrm{NaCl}$ by successive transfer of the culture to media with increased $\mathrm{NaCl}$ concentrations; no growth was recorded at $4.5 \%(\mathrm{w} / \mathrm{v}) \mathrm{NaCl}$ or higher.

Positive utilization of a carbon substrate was recorded for strain JW/SA-NV4 ${ }^{\mathrm{T}}$ when $\Delta \mathrm{OD}_{600}$ was twice that of cultures containing only the basal $0.5 \mathrm{~g} \mathrm{l}^{-1}$ concentration of yeast extract $\left(\Delta \mathrm{OD}_{600}=0.015\right)$. Strain JW/SA-NV4 ${ }^{\mathrm{T}}$ utilized xylose, glucose, mannose, xylan, pyruvate, fructose, ribose, cellobiose, Casamino acids, mannitol, tryptone, peptone and yeast extract. Strain JW/SA-NV4 ${ }^{\mathrm{T}}$ did not utilize sucrose, glycine betaine, galactose, lactose, xylitol, sorbitol, inositol, arabinose, starch or cellulose. Yeast extract was required for growth, with about $10 \mathrm{~g} \mathrm{l}^{-1}$ saturation in media containing $5 \mathrm{~g}$ xylose $1^{-1}$. Acetate was the major fermentation product of strain JW/SA-NV4 ${ }^{\mathrm{T}}$ when grown with glucose as the carbon substrate with 2.22.4 mol acetate produced per mol glucose consumed, suggesting a homoacetogenic fermentation, although a trace amount of lactate was occasionally detected $(<0.1 \mathrm{~mol}$ lactate produced per mol glucose consumed; $\mathrm{H}_{2}$ and $\mathrm{CO}_{2}$ were not quantified) (Drake et al., 2008). Fermentation products were similar when strain JW/SA$\mathrm{NV}^{\mathrm{T}}{ }^{\mathrm{w}}$ was grown with either xylan or xylose.

Biochemical features of strain JW/SA-NV4 ${ }^{\mathrm{T}}$, and phylogenetically related taxa (see $16 \mathrm{~S}$ rRNA gene sequence analysis below) Thermosediminibacter oceani JW/IW-1228 $\mathrm{P}^{\mathrm{T}}$ and Thermosediminibacter litoriperuensis JW/YJL-1230-7/2 ${ }^{\mathrm{T}}$ were tested using the API ZYM 25200 (bioMérieux) system (Thermovenabulum ferriorganovorum strain Z- $9801^{\mathrm{T}}$ is not available from DSMZ). For all three strains, strong positive reactions were observed for acid phosphatase and naphtholAS-BI-phosphohydrolase. A strong $\alpha$-glucosidase reaction was observed for Thermosediminibacter oceani JW/IW$1228 \mathrm{P}^{\mathrm{T}}$, but not for strain JW/SA-NV4 ${ }^{\mathrm{T}}$ or Thermosediminibacter litoriperuensis JW/YJL-1230-7/2 ${ }^{\mathrm{T}}$ (Table 1).

The potential for strain JW/SA-NV4 ${ }^{\mathrm{T}}$ to utilize various electron acceptors was studied using mineral media containing $1 \mathrm{~g}$ yeast extract $\mathrm{l}^{-1}$ as an electron donor. Thiosulfate $(15 \mathrm{mM})$ and sulfur $\left(0.96 \mathrm{~g} \mathrm{l}^{-1}\right)$ were reduced to sulfide, as determined by the formation of $\mathrm{CuS}$ upon the addition of $\mathrm{CuSO}_{4}$. Sulfate $(15 \mathrm{mM})$ and sulfite $(5 \mathrm{mM})$ were not reduced to sulfide. To determine the tolerance of oxygen by strain JW/SA-NV4 ${ }^{\mathrm{T}}, 140 \mathrm{ml}$ of the inoculated mineral media (containing $0.5 \mathrm{~g}$ yeast extract $\mathrm{l}^{-1}$ and $1 \mathrm{~g}$ glucose $1^{-1}$ ) were incubated in 11 Media Storage Bottles model 1395 (Pyrex) in the horizontal position. Media were prepared to be anoxic, by gassing with $\mathrm{N}_{2}$ without reducing agents, and volumes of air were injected via syringes into the headspace. Liquid cultures of strain JW/SA-NV4 ${ }^{\mathrm{T}}$ tolerated an atmosphere containing up to $0.1 \% \mathrm{O}_{2}$; no growth was observed with an atmosphere of $0.2 \% \mathrm{O}_{2}$ or higher.

Lyophilized cell material was used to analyse the phospholipid fatty acid (PLFA) content of strain JW/SA-NV4 ${ }^{\mathrm{T}}$. Lipid extraction was performed as described by Wagner et al. (2008) based on the protocols of Zhang et al. (2004) and White et al. (1979). GC-MS analyses of the fatty acid methyl esters were performed using an HP5890 GC equipped with a $30 \mathrm{~m}$, HP5-MSI column and programmable temperature vaporizing inlet and coupled to a HP5972 mass spectrometer. The major PLFAs of strain JW/ SA-NV4 ${ }^{\mathrm{T}}$ were $\mathrm{i} 15: 0$ (46.8\%), a15:0 (26.7\%), 15:0 $(6.3 \%)$ and $16: 0$ (5.5\%) (Table 2).

For cell-wall analysis of strain JW/SA-NV4 $4^{\mathrm{T}}$, peptidoglycan was isolated after disintegration of cells with glass beads in a Vibrogen cell mill (Edmund Bühler) and then subjected to a trypsin digestion according to the method of Schleifer \& Seidl (1985). Strain JW/SA-NV4 ${ }^{\mathrm{T}}$ had a peptidoglycan type Al $\gamma$ (Schleifer \& Kandler, 1972; P. Schumann, personal communication).

Genomic DNA for the analysis of the $\mathrm{G}+\mathrm{C}$ content of strain JW/SA-NV4 $4^{\mathrm{T}}$ was obtained through a large-scale phenol/chloroform genomic DNA extraction, essentially as described by Wilson (1997), but without performing the final caesium chloride gradient purification step described. The DNA G $+\mathrm{C}$ content was measured by using the HPLC method of Mesbah et al. (1989), with S1 nuclease (Invitrogen) and 0.3 M sodium acetate ( $\mathrm{pH}$ 5.0) modifications described by Lee et al. (2005). The DNA G+C content of strain JW/SA-NV4 ${ }^{\mathrm{T}}$ was $38.6 \mathrm{~mol} \%$; standard deviation, $0.4(n=4)$. 
Table 1. Morphological and physiological characteristics of strain JW/SA-NV4 ${ }^{\top}$ and close relatives

Strains: 1, JW/SA-NV4 ${ }^{\mathrm{T}}$ (C. acetigignens sp. nov.; data from this study); 2, Thermosediminibacter oceani JW/IW-1228P ${ }^{\mathrm{T}}$ (Lee et al., 2005; this study); 3, Thermosediminibacter litoriperuensis JW/YJL-1230-7/2 ${ }^{\mathrm{T}}$ (Lee et al., 2005; this study); 4, Thermovenabulum ferriorganovorum Z-9801 ${ }^{\mathrm{T}}(\mathrm{Zavarzina}$ et al., 2002). +, Positive; -, negative; ND, not determined.

\begin{tabular}{|c|c|c|c|c|}
\hline Characteristic & 1 & 2 & 3 & 4 \\
\hline Isolation source & $\begin{array}{c}\text { Terrestrial hot spring, } \\
\text { Nevada, USA }\end{array}$ & $\begin{array}{l}\text { Subseafloor, } \\
\text { Peru Margin }\end{array}$ & $\begin{array}{l}\text { Subseafloor, } \\
\text { Peru Margin }\end{array}$ & $\begin{array}{c}\text { Terrestrial hot spring, } \\
\text { Uzon Caldera, Russian } \\
\text { Far East }\end{array}$ \\
\hline Cell size $(\mu \mathrm{m})$ & $0.4-0.8 \times 3-6$ & $0.2-0.7 \times 1.5-16$ & $0.3-0.5 \times 2-10$ & $0.5-0.6 \times 1.5-7.0$ \\
\hline Flagella & No flagella observed & Flagella observed & Retarded peritrichous flagella & Peritrichous flagella \\
\hline $\begin{array}{l}\text { Temperature range for } \\
\text { growth }\left({ }^{\circ} \mathrm{C}\right)\end{array}$ & $44-74$ & $52-76$ & $43-76$ & $45-76$ \\
\hline Optimum temperature $\left({ }^{\circ} \mathrm{C}\right)$ & 61 & 68 & 64 & $63-65$ \\
\hline $\mathrm{pH}$ range for growth & $6.8-8.8$ & $6.3-9.3$ & $5-9.5$ & $4.8-8.2$ \\
\hline Optimum pH & 8.4 & 7.5 & $7.9-8.4$ & $6.7-6.9$ \\
\hline Salinity $(\% \mathrm{NaCl}, \mathrm{w} / \mathrm{v})$ & $0-4.0$ & $0-6.0$ & $0-4.5$ & $0-3.5$ \\
\hline DNA G $+C$ content $(\mathrm{mol} \%)$ & 38.6 & 46.3 & 45.2 & 36 \\
\hline Gram stain & - & - & - & + \\
\hline Spores observed & - & - & - & + \\
\hline$\alpha$-Glucosidase & - & + & - & $\mathrm{ND}$ \\
\hline \multicolumn{5}{|l|}{ Utilization of: } \\
\hline Galactose & - & + & + & - \\
\hline Glucose & + & + & + & - \\
\hline Inositol & - & + & + & $\mathrm{ND}$ \\
\hline Sorbitol & - & + & - & $\mathrm{ND}$ \\
\hline Sucrose & - & + & + & + \\
\hline Trehalose & ND & + & $\mathrm{ND}$ & ND \\
\hline Xylitol & - & - & + & ND \\
\hline $16: 1$ PLFA & + & - & - & ND \\
\hline $18: 0$ PLFA & - & + & + & $\mathrm{ND}$ \\
\hline
\end{tabular}

Table 2. Phospholipid fatty acid contents (\%) of strains JW/ SA-NV4 ${ }^{\top}$, JW/IW-1228P ${ }^{\top}$ and JW/YJL-1230-7/2 ${ }^{\top}$

Strains: 1, JW/SA-NV4 ${ }^{\mathrm{T}}$ (C. acetigignens sp. nov.; data from this study); 2, Thermosediminibacter oceani JW/IW-1228 $\mathrm{P}^{\mathrm{T}}$ (Lee et al., 2005); 3, Thermosediminibacter litoriperuensis JW/YJL-1230-7/2 ${ }^{\mathrm{T}}$ (Lee et al., 2005). ND, Not detected.

\begin{tabular}{|lccc|}
\hline Fatty acid methyl ester & $\mathbf{1}$ & $\mathbf{2}$ & $\mathbf{3}$ \\
\hline $\mathrm{i} 13: 0$ & 2.7 & $\mathrm{ND}$ & $\mathrm{ND}$ \\
$14: 0$ & 3.0 & 1.8 & 1.7 \\
$\mathrm{i} 15: 0$ & 46.8 & 56.2 & 16.7 \\
$\mathrm{a} 15: 0$ & 26.7 & 6.7 & 3.8 \\
$15: 0$ & 6.3 & 5.0 & 2.6 \\
$\mathrm{i} 16: 0$ & $\mathrm{ND}$ & 1.9 & 1.6 \\
$16: 1 \omega 9 c$ & $\mathrm{ND}$ & 5.6 & 19.9 \\
$16: 1$ & 2.8 & $\mathrm{ND}$ & $\mathrm{ND}$ \\
$16: 0$ & 5.5 & 7.5 & 15.5 \\
$\mathrm{i} 17: 0$ & 2.4 & 9.6 & 4.5 \\
$17: 0$ & $\mathrm{ND}$ & 1.0 & $\mathrm{ND}$ \\
$18: 2 \omega 6 c$ & $\mathrm{ND}$ & $\mathrm{ND}$ & 1.4 \\
$18: 1 \omega 9 c$ & 3.9 & 3.3 & 20.3 \\
$18: 1 \omega 9 t / 18: 1 \omega 7 c^{*}$ & $\mathrm{ND}$ & $\mathrm{ND}$ & 6.3 \\
$18: 0$ & $\mathrm{ND}$ & 1.5 & 5.7 \\
& & & \\
\hline
\end{tabular}

${ }^{\star} 18: 1 \omega 9 t / 18: 1 \omega 7 c$ were unresolved in this analysis.
Genomic DNA for amplification of the 16S rRNA gene sequence was extracted using an UltraClean DNA isolation kit (Mo Bio). PCRs were prepared with the bacterial domain-specific primer set 27F and 1492R (Lane, 1991), using GoTaq (Promega), and thermocycler conditions described previously by Lee et al. (2005). Amplification products were purified using a QIAquick PCR purification kit (Qiagen) and sequenced by Macrogen. Due to unexplained difficulties with the $27 \mathrm{~F}$ sequencing reaction, an additional reverse sequencing reaction was performed using a modified Univ907 $\mathrm{R}$ primer (5'-CGTCAATTCCTTTGAGTTT-3') (Amann et al., 1992; Loy et al., 2007). Sequencing results were aligned using Sequencher v4.1.4 (Gene Codes). A multiple sequence alignment was created with CLUSTAL $\mathrm{W}$ (Thompson et al., 1994) and subsequent phylogenetic analyses were performed using MEGA4 software (Tamura et al., 2007). Phylogenetic trees (Fig. 2) were inferred by using the neighbour-joining method (Saitou \& Nei, 1987) with the Jukes and Cantor model (Jukes \& Cantor, 1969). The $16 \mathrm{~S}$ rRNA gene sequence of JW/SA-NV4 ${ }^{\mathrm{T}}$ was deposited at GenBank. Phylogenetic analyses placed strain JW/SA-NV4 ${ }^{\mathrm{T}}$ within the Thermoanaerobacterales Incertae Sedis Family III (Ludwig et al., 2009) of the phylum Firmicutes (Fig. 2). The closest phylogenetic neighbours were the marine 


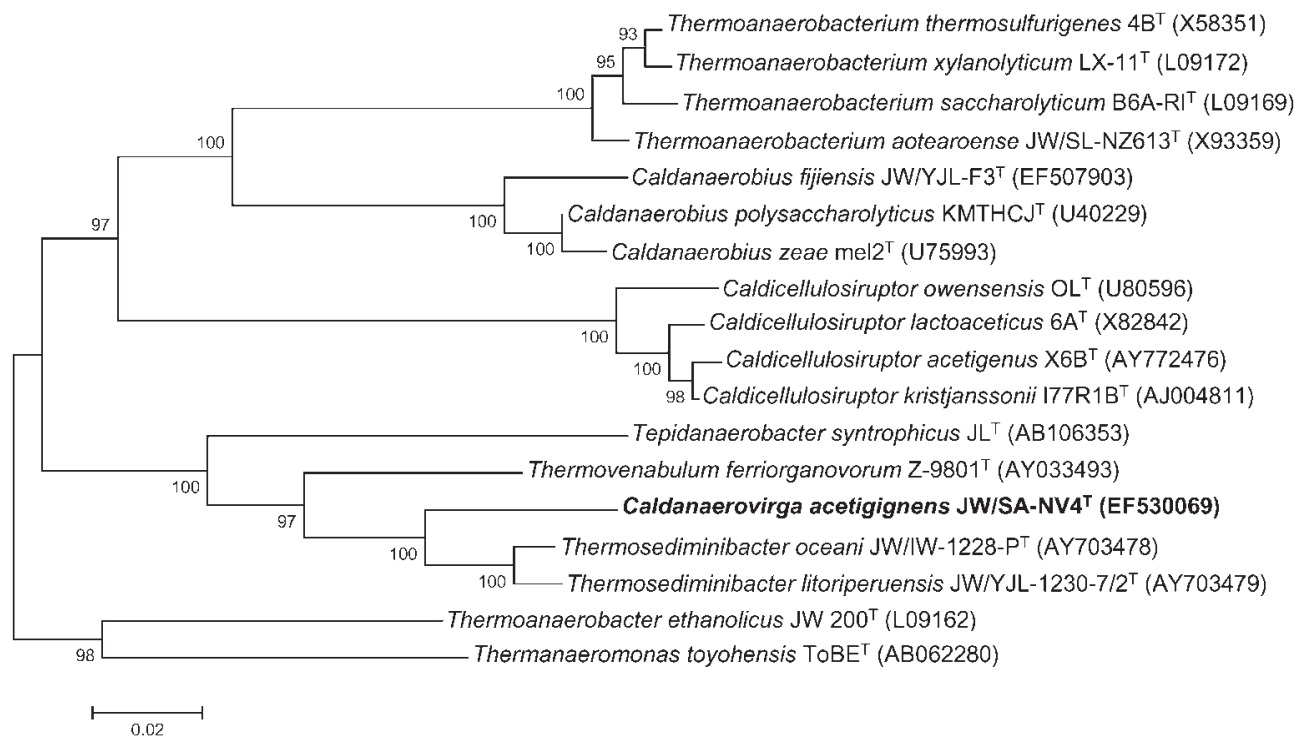

Fig. 2. $16 \mathrm{~S}$ rRNA gene sequence-based phylogenetic dendrogram of strain JW/SA-NV4 ${ }^{\top}$ and related taxa. The tree was constructed using the neighbour-joining method (Saitou \& Nei, 1987) and the Jukes and Cantor distance corrections (Jukes \& Cantor, 1969). Numbers at nodes are bootstrap percentages based on 1000 replicates. Bar, 2 nucleotide substitutions per 100 nucleotides. All positions containing alignment gaps and missing data were eliminated only in pairwise sequence comparisons (Pairwise deletion option). There was a total of 1836 positions in the final dataset. Phylogenetic analyses were conducted in MEGA4 (Tamura et al., 2007).

Thermosediminibacter oceani $\mathrm{JW} / \mathrm{IW}-1228 \mathrm{P}^{\mathrm{T}}(94.2 \%$ gene sequence similarity) and Thermosediminibacter litoriperuensis JW/YJL-1230-7/2 ${ }^{\mathrm{T}}$ (94.0\%), both isolated from eastern equatorial Pacific sediment of the Peru Margin (Lee et al., 2005), and Thermovenabulum ferriorganovorum Z- $9801^{\mathrm{T}}(90.3 \%)$, isolated from a terrestrial hot spring in the Uzon Caldera, Kamchatka, Far East Russia (Zavarzina et al., 2002).

Nearly all of the recognized anaerobic alkalithermophilic Bacteria belong to the Firmicutes (Kevbrin et al., 2004; Wiegel, 1998); indeed, strain JW/SA-NV4 ${ }^{\mathrm{T}}$ belongs within this clade, specifically within the Thermoanaerobacterales Incertae Sedis Family III (Ludwig et al., 2009). Within the Thermoanaerobacterales Incertae Sedis Family III, the genera Thermoanaerobacterium, Caldicellulosiruptor and Caldanaerobius form well-defined phylogenetic clades (Fig. 2). The other recognized genera of the Thermoanaerobacterales Incertae Sedis Family III include Thermosediminibacter, Thermovenabulum and Tepidanaerobacter. A hindrance to assigning a taxonomic affiliation for strain JW/SA-NV4 $4^{\mathrm{T}}$ is that at present there are only four recognized species classified within the three genera set of Thermosediminibacter, Thermovenabulum and Tepidanaerobacter. Naturally, as additional species are described within these genera, a more complete view of their phylogenetic relationships will emerge. Strain JW/SA$\mathrm{NV} 4{ }^{\mathrm{T}}$ had $94.2 \% 16 \mathrm{~S}$ rRNA gene sequence similarity to Thermosediminibacter oceani JW/IW- $1228 \mathrm{P}^{\mathrm{T}}$ and $94.0 \%$ similarity to Thermosediminibacter litoriperuensis JW/YJL-
$1230-7 / 2^{\mathrm{T}}$. Although it is a topic of continued discussion, some microbial systematicists regard distance values of $5 \%$ as differentiation at the genus level (Schloss \& Handelsman, 2004; references therein). The notion that strain JW/SA$\mathrm{NV} 4^{\mathrm{T}}$ should be classified as a novel species within a novel genus is also supported by biochemical and physiological differences (Table 1). Thus, we propose that strain JW/SA$\mathrm{NV} 4^{\mathrm{T}}$ belongs to a novel genus. The differences include the following properties. The Thermosediminibacter species have flagella (Lee et al., 2005), whereas no flagella were observed for strain JW/SA-NV4 ${ }^{\mathrm{T}}$. A small percentage of the cells in cultures of Thermosediminibacter oceani, Thermosediminibacter litoriperuensis and Thermovenabulum ferriorganovorum exhibit a characteristic branched cell morphology (Lee et al., 2005; Zavarzina et al., 2002), which was not observed with cells of strain JW/SA-NV4 ${ }^{\mathrm{T}}$. There are differences in the PLFA profiles of strain JW/SA-NV4 ${ }^{\mathrm{T}}$ and the Thermosediminibacter species. The 16:1 PLFA was detected for JW/SA-NV4 ${ }^{\mathrm{T}}$, but not for either Thermosediminibacter oceani JW/IW- $1228 \mathrm{P}^{\mathrm{T}}$ or Thermosediminibacter litoriperuensis JW/YJL-1230-7/2 ${ }^{\mathrm{T}}$; the $18: 0$ PLFA was found within Thermosediminibacter oceani JW/ IW-1228 $\mathrm{P}^{\mathrm{T}}$ and Thermosediminibacter litoriperuensis JW/ YJL-1230-7/2 ${ }^{\mathrm{T}}$, but was not found in strain JW/SA-NV4 ${ }^{\mathrm{T}}$; the a15:0 amount of $26.7 \%$ was found for strain JW/SA$\mathrm{NV}^{\mathrm{T}}$, with much lower values of 6.7 and $3.8 \%$ for Thermosediminibacter oceani JW/IW- $1228 \mathrm{P}^{\mathrm{T}}$ and Thermosediminibacter litoriperuensis JW/YJL-1230-7/2 ${ }^{\mathrm{T}}$, respectively (Table 2). There are also differences in the utilization of carbon substrates, e.g., both Thermosedminibacter species 
can utilize galactose and sucrose, whereas strain JW/SA$\mathrm{NV} 4^{\mathrm{T}}$ cannot use either. The isolation source of strain JW/ $\mathrm{SA}-\mathrm{NV}_{4}{ }^{\mathrm{T}}$ was terrestrial hot spring whereas all the Thermosediminibacter strains were derived from marine sediment (Lee et al., 2005). The difference in the $G+C$ content of the genomic DNA of strain JW/SA-NV4 ${ }^{\mathrm{T}}$ and the Thermosedminibacter species is approximately $7 \mathrm{~mol} \%$.

\section{Description of Caldanaerovirga gen. nov.}

Caldanaerovirga (Cal.da.na.e.ro.vir'ga. L. adj. caldus hot; Gr. pref. an not; Gr. n. aer air; L. fem. n. virga rod; N.L. fem. n. Caldanaerovirga rod that grows in the absence of air at elevated temperatures).

Anaerobic thermophilic, Gram-type positive. Cell wall has a peptidoglycan type $\mathrm{A} 1 \gamma$. Belongs to the class Clostridia. The DNA G $+\mathrm{C}$ content is around $38 \mathrm{~mol} \%$. The type species is Caldanaerovirga acetigignens.

\section{Description of Caldanaerovirga acetigignens sp. nov.}

Caldanaerovirga acetigignens (a.ce.ti.gig' nens. L. n. acetum vinegar; L. v. gignere to produce; N.L. part. adj. acetigignens vinegar- or acetic acid-producing).

Exhibits the following properties in addition to those given in the genus description. During exponential growth, cells are straight or slightly bent rods of $0.4-$ $0.8 \mu \mathrm{m}$ in width and 3-6 $\mu \mathrm{m}$ in length. Cells from stationary phase are more variable in size and shape, showing a more expressed curved or bent morphology. Neither flagella or motility nor sporulation are observed. Cells stain Gram-negative but are phylogenetically Gramtype positive. Growth with glucose as carbon and energy source occurs between $\mathrm{pH}^{25}{ }^{\circ} \mathrm{C} 6.8$ and 8.8 (optimum, $\mathrm{pH}$ 8.4); no growth occurs after $200 \mathrm{~h}$ of incubation at $\mathrm{pH} 9.0$ or above, or at 6.5 or below. Grows at $44-74{ }^{\circ} \mathrm{C}$ (glucose); no growth occurs after $300 \mathrm{~h}$ of incubation at $76{ }^{\circ} \mathrm{C}$ or above, or at $42{ }^{\circ} \mathrm{C}$ or below. Optimum temperature for growth is around 62 and $66{ }^{\circ} \mathrm{C}$ when grown on glucose and xylose, respectively. The shortest doubling time observed was approximately $4 \mathrm{~h}$ (glucose) and $3.4 \mathrm{~h}$ (xylose). Chemo-organotroph. Positive for utilization of xylose, glucose, mannose, xylan, pyruvate, fructose, ribose, Casamino acids, mannitol, tryptone, peptone, cellobiose and yeast extract. Acetate $(2.2-2.4 \mathrm{~mol} /$ glucose $)$ is the major fermentation product when grown with glucose suggesting a homoacetogenic fermentation. Yeast extract is required for growth. Does not utilize sucrose, glycine betaine, galactose, lactose, xylitol, sorbitol, inositol, arabinose, starch or cellulose. Using mineral media containing $1 \mathrm{~g}$ yeast extract $1^{-1}$ as an electron donor, thiosulfate and sulfur, but not sulfate or sulfite, are reduced to sulfide. Growth occurs in the presence of an atmosphere containing $0.1 \% \mathrm{O}_{2}$ but not $0.2 \%$. Positive for acid phosphatase and naphthol-AS-BI-phosphohydrolase. Major PLFAs of strain JW/SA-NV4 ${ }^{\mathrm{T}}$ are $\mathrm{i} 15: 0$, a15 $: 0$,
$15: 0$ and $16: 0$. The $\mathrm{G}+\mathrm{C}$ content of the DNA of the type strain is $38.6 \mathrm{~mol} \%$; standard deviation 0.4 (HPLC).

The type strain, JW/SA-NV4 ${ }^{\mathrm{T}}\left(=\mathrm{DSM} 18802^{\mathrm{T}}=\mathrm{ATCC}\right.$ BAA- $1454^{\mathrm{T}}$ ), was isolated from Trego hot spring $\left(40^{\circ} 46^{\prime} 12^{\prime \prime} \mathrm{N} 119^{\circ} 6^{\prime} 46^{\prime \prime} \mathrm{W}\right)$, Black Rock Desert, northwestern Nevada, USA.

\section{Acknowledgements}

Funding for this research was provided by the National Science Foundation MIP Program to JW/CLZ/CSR (MCB 0348180), as well as a grant from United States Department of States (USDOS) and Higher Education Commission, Government of Pakistan. We thank P. Schumann at DSMZ for assistance with the cell wall analysis, W. B. Whitman for his help with the DNA G $+\mathrm{C}$ content determination, and G. Mills and N. Garvin for assistance with lipid analysis.

\section{References}

Amann, R. I., Stromley, J., Devereux, R., Key, R. \& Stahl, D. A. (1992). Molecular and microscopic identification of sulfate-reducing bacteria in multispecies biofilms. Appl Environ Microbiol 58, 614-623.

Biely, P. (1985). Microbial xylanolytic systems. Trends Biotechnol 3, 286-290.

Drake, H., Gößner, A. \& Daniel, S. (2008). Old acetogens, new light. In Incredible Anaerobes: From Physiology to Genomics to Fuels, pp. 100-128. Edited by J. Wiegel, R. J. Maier \& M. W. W. Adams. Boston: Blackwell Publishing.

Himmel, M. E., Ding, S. Y., Johnson, D. K., Adney, W. S., Nimlos, M. R., Brady, J. W. \& Foust, T. D. (2007). Biomass recalcitrance: engineering plants and enzymes for biofuels production. Science 315, 804-807.

Hose, R. K. \& Taylor, B. E. (1974). Geothermal systems of northern Nevada: USGS-OFR-74-271, Geological Survey, Reston, VA (USA).

Jukes, T. H. \& Cantor, C. R. (1969). Evolution of protein molecules. In Mammalian Protein Metabolism, vol. 3, pp. 21-132. Edited by H. N. Munro. New York: Academic Press.

Kevbrin, V. V., Romanek, C. S. \& Wiegel, J. (2004). Alkalithermophiles: a double challenge from extreme environments. In Origins: Genesis, Evolution and Diversity of Life, pp. 395-412. Edited by J. Seckbach. Dordrecht: Kluwer Academic Publishers.

Lane, D. J. (1991). 16S/23S rRNA sequencing. In Nucleic Acid Techniques in Bacterial Systematics, pp. 115-175. Edited by E. Stackebrandt \& M. Goodfellow. Chichester: Wiley.

Lee, Y.-J., Wagner, I. D., Brice, M. E., Kevbrin, V. V., Mills, G. L., Romanek, C. S. \& Wiegel, J. (2005). Thermosediminibacter oceani gen. nov., sp. nov. and Thermosediminibacter litoriperuensis sp. nov., new anaerobic thermophilic bacteria isolated from Peru Margin. Extremophiles 9, 375-383.

Ljungdahl, L. G. \& Wiegel, J. (1986). Working with anaerobic bacteria. In Manual of Industrial Microbiology, pp. 115-127. Edited by A. L. Demain \& N. A. Solomon. Washington, DC: American Society for Microbiology.

Loy, A., Maixner, F., Wagner, M. \& Horn, M. (2007). probeBase - an online resource for rRNA-targeted oligonucleotide probes: new features 2007. Nucleic Acids Res 35, D800.

Ludwig, W., Schleifer, K. \& Whitman, W. (2009). Revised road map to the phylum Firmicutes. In Bergey's Manual of Systematic Bacteriology, vol. 3. Edited by P. De Vos, G. Garrity, D. Jones, N. Krieg, W. Ludwig, F. Rainey, K. Schleifer \& W. Whitman. New York: Springer-Verlag. (in Press) 
Mesbah, M., Premachandran, U. \& Whitman, W. B. (1989). Precise measurement of the $\mathrm{G}+\mathrm{C}$ content of deoxyribonucleic acid by highperformance liquid chromatography. Int J Syst Bacteriol 39, 159-167.

Pearson, A., Huang, Z., Ingalls, A. E., Romanek, C. S., Wiegel, J., Freeman, K. H., Smittenberg, R. H. \& Zhang, C. L. (2004). Nonmarine crenarchaeol in Nevada hot springs. Appl Environ Microbiol 70, 52295237.

Saitou, N. \& Nei, M. (1987). The neighbor-joining method: a new method for reconstructing phylogenetic trees. Mol Biol Evol 4, 406-425.

Schleifer, K. H. \& Kandler, O. (1972). Peptidoglycan types of bacterial cell walls and their taxonomic implications. Bacteriol Rev 36, 407-477.

Schleifer, K. H. \& Seidl, P. H. (1985). Chemical composition and structure of murein. In Chemical Methods in Bacterial Systematics, pp. 201-219. Edited by M. Goodfellow \& D. E. Minnikin. London: Academic Press.

Schloss, P. D. \& Handelsman, J. (2004). Status of the microbial census. Microbiol Mol Biol Rev 68, 686-691.

Shao, W., DeBlois, S. \& Wiegel, J. (1995). A high-molecular-weight, cell-associated xylanase isolated from exponentially growing Thermoanaerobacterium sp. strain JW/SL-YS485. Appl Environ Microbiol 61, 937-940.

Tamura, K., Dudley, J., Nei, M. \& Kumar, S. (2007). MEGA4: Molecular Evolutionary Genetics Analysis (MEGA) software version 4.0. Mol Biol Evol 24, 1596.

Thompson, J. D., Higgins, D. G. \& Gibson, T. J. (1994). Clustal W: improving the sensitivity of progressive multiple sequence alignment through sequence weighting, position-specific gap penalties and weight matrix choice. Nucleic Acids Res 22, 4673-4680.

Wagner, I. \& Wiegel, J. (2008). Diversity of thermophilic anaerobes. In Incredible Anaerobes: From Physiology to Genomics to Fuels, pp. 1-43. Edited by J. Wiegel, R. J. Maier \& M. W. W. Adams. Boston: Blackwell Publishing.
Wagner, I. D., Zhao, W., Zhang, C., Romanek, C. S., Rohde, M. \& Wiegel, J. (2008). Thermoanaerobacter uzonensis sp. nov., an anaerobic thermophilic bacterium isolated from a hot spring within the Uzon Caldera, Kamchatka, Far East Russia. Int J Syst Evol Microbiol 58, 2565-2573.

White, D. C., Davis, W. M., Nickels, J. S., King, J. D. \& Bobbie, R. J. (1979). Determination of the sedimentary microbial biomass by extractible lipid phosphate. Oecologia 40, 51-62.

Widdel, F. \& Bak, F. (1992). Gram-negative mesophilic sulfatereducing bacteria. In The Prokaryotes, pp. 3352-3378. Edited by A. Balows, H. Trüper, M. Dworkin, W. Harder \& H. Schleifer. New York: Springer.

Wiegel, J. (1981). Distinction between gram reaction and the gram type of bacteria. Int J Syst Bacteriol 31, 88.

Wiegel, J. (1998). Anaerobic alkalithermophiles, a novel group of extremophiles. Extremophiles 2, 257-267.

Wiegel, J. \& Kevbrin, V. V. (2004). Alkalithermophiles. Biochem Soc Trans 32, 193-198.

Wilson, K. (1997). Preparation of genomic DNA from bacteria. In Current Protocols in Molecular Biology, pp. 2.4.1-2.4.5. Edited by F. M. Ausubel, R. Brent, R. E. Kingston, D. D. Moore, J. G. Seidman, J. A. Smith \& K. Struhl. New York: Greene Publishing and WileyInterscience.

Zavarzina, D. G., Tourova, T. P., Kuznetsov, B. B., BonchOsmolovskaya, E. A. \& Slobodkin, A. I. (2002). Thermovenabulum ferriorganovorum gen. nov., sp. nov., a novel thermophilic, anaerobic, endospore-forming bacterium. Int J Syst Evol Microbiol 52, 17371743.

Zhang, C. L., Fouke, B. W., Bonheyo, G. T., Peacock, A. D., White, D. C., Huang, Y. \& Romanek, C. S. (2004). Lipid biomarkers and carbonisotopes of modern travertine deposits (Yellowstone National Park, USA): implications for biogeochemical dynamics in hot-spring systems. Geochim Cosmochim Acta 68, 3157-3169. 